\section{The calm after the storm}

\section{London}

THE announcement of next year's British science budget, which for the first time will top $£ 1,000$ million, has brought a collective sigh of relief from the UK research councils. Following the 1991-92 public expenditure statement, which education and science secretary Kenneth Clarke described as a "real terms level settlement" for research but which the research councils denounced as a cut in science funding, the figure for 1992-93 should slow the rush to cut spending that has occupied the councils for much of the current year. Clarke, speaking at a press conference last week, said the $£ 1,006$ million budget represents a real increase of 2.5 per cent over last year's figure, if the government's prediction for the rate of inflation over the coming year holds true.

The heads of the research councils gave the announcement a cautious welcome. "A distinct improvement," said Medical Research Council (MRC) secretary Dai Rees. Sir Mark Richmond, chairman of the Science and Engineering Research Council (SERC), which cut back research grants and announced a review of its support for large research facilities after last year's public expenditure announcement, agreed that the budget would allow for a small amount of growth over this year's spending, but added: "I'm not throwing my hat in the air." The cuts already made by SERC, including the well-publicized decision to close the Nuclear Structure Facility at the council's Daresbury Laboratory in Cheshire, would be unaffected by the new budget, he said.

Tom Blundell, director-general of the Agricultural and Food Research Council (AFRC) welcomed the additional money, but said that this may be too little to cover the $£ 10$-million shortfall that AFRC is expecting in 1992-93, mostly because of the difficulty in selling empty laboratory buildings (see Nature 353, 690; 24 October 1991). Clarke said last week that it is up to AFRC to convince the Advisory Board for the Research Councils that it needs extra funds. (The board will meet over the coming months to discuss the allocation of the new budget among the research councils). But AFRC "does have a bit of a point," he said.

The MRC's Rees said he was particularly pleased that the planning figures for science spending over the next three years allow for a realistic growth in the budget, taking account of the expected rate of inflation. Traditionally, these planning figures have shown a budget declining in real terms (a pattern described as "planners" droop" by many civil servants), despite the fact that more money was usually made available later. This has made it difficult for the research councils to plan their future spending. Characteristically, Richmond was more cautious, pointing out that next year will see a general election: the next government may not stick to the planning figures announced last week.

The government's spending plans are seen generally to be a balance between the need to woo voters for the forthcoming election, and the restrictions placed on public spending by the current economic recession. According to the government. spending by the Department and Education and Science has been made a priority, along with the budget of the National Health Service.

Within the education budget, the polytechnics, colleges and universities - soon to become a unified system for higher education (see Nature 351. 257: 23 May 1991 ) - will get 5.5 per cent more in real terms in 1992-93 than in the current year. But given the forecast increase in student numbers, higher-education institutions will be expected to teach each student for a slightly smaller cost. Clarke said he was expecting the higher-education system to produce "efficiency gains" of around 2 per cent.

Peter Aldhous

\title{
'Activist' stance by UK government
}

\section{London}

THE British government has surprised environmentalist groups with its campaign to encourage homeowners to join its new $£ 10$-million, three-year scheme to encourage energy efficiency. Full-page newspaper advertisements published last week juxtapose images of the 'great storm' of 1987 (see Nature 329, 750; 1987), which devastated southern England, causing millions of pounds worth of damage and claiming 19 lives, with the stark message: "Global Warming: We have been warned."

"It's leaping ahead of the science," says Simon Roberts, energy campaigner for the British environmentalist group Friends of the Earth, but he adds that he is nonetheless pleased that the government seems to have recognized the need to convince the British public that global warming is an important issue. However, if Friends of the Earth had placed the same advertisements, he observes wryly, "we'd have been torn apart."

To be fair, the text accompanying the images does say that climatologists have not yet proved a link between the excess greenhouse effect and the extreme weather of October 1987, but the public seems likely to overlook the fine print.

The British government's apparent adoption of an 'activist' stance is in sharp contrast to the position of the US Administration, which has long stressed the scientific uncertainty surrounding predictions of climate change, and it illustrates the deep rift between the countries of the European Communities and the United States over global warming policy. This impasse is hampering attempts to produce a meaningful international climate convention in time for the United Nations 'Earth Summit' in June 1992.

Roberts last week also found himself in the unaccustomed position of welcoming the UK Department of Energy's latest policy on renewable energy sources. Following a Friends of the Earth campaign to increase the emphasis on renewables, the department has announced that it will provide a guaranteed market for $457 \mathrm{MW}$ of electricity generated from renewables between 1992 and 1998 - twice the fig-
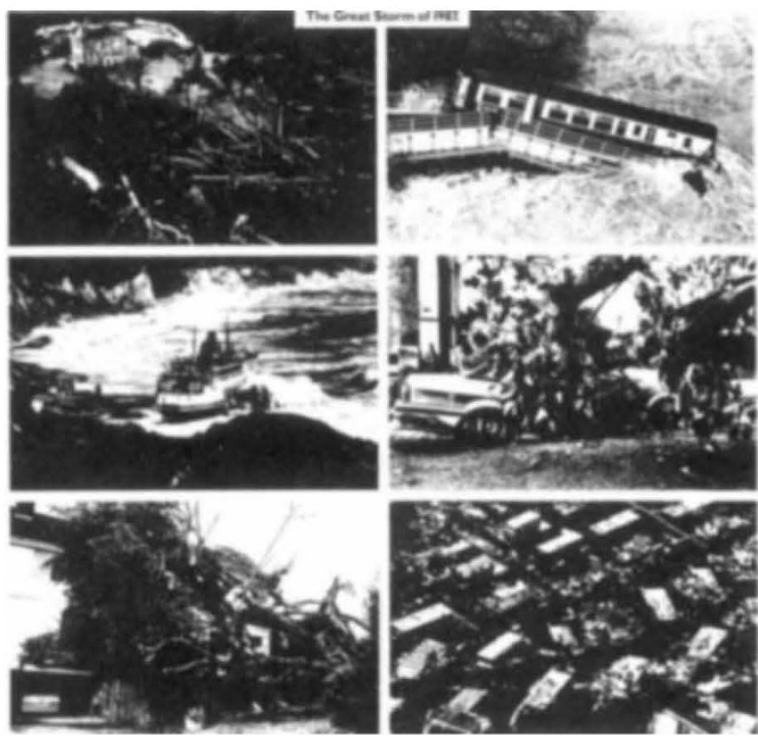

\section{Global Warming.} We have been warned.

ure it had previously agreed, but still a tiny percentage of Britain's total generating capacity of about $70,000 \mathrm{MW}$

Peter Aldhous 